Huseynov Fuad Vagif,

Doctoral candidate, UNEC

ORCID ID: 0000-0003-4703-4171

DOI: $10.32702 / 2306-6806.2020 .10 .117$

\title{
CONCEPTUAL ISSUES OF TAX ANALYSIS
}

Гусейнов Фуад Вагіф огли,

Аокторант, Азербайджанський Аержавний Економічний Університет, (UNEC)

\section{КОНЦЕПТУААЬНІ ПИТАННЯ ПОААТКОВОГО АНААІЗУ}

We determine which terms shall be applied in tax analysis by revealing the differences between terminological apparatus of accounting and tax accounting by the way of use of comparative analysis and dialectic synthesis methods.

Several scientists engaging in learning of issues connected to the field of tax analysis presented and used certain terms and conceptions in their in vestigations. The most concepts for purposes of this research cover the follows: tax burden, operational tax costs, tax environment, tax discounts. The use of special terminology exists in official documents in one or other form concerning the tax analysis conducted by public authorities. It is required to analyze and generalize these terms in order to conduct the said research.

Formed as a result of the synthesis of a number of special and sectoral areas of scientific knowledge, and only in the 20th century became an independent science, economic analysis, under the influence of the newly emerging needs of practice, creates new promising scientific areas, one of which is tax analysis as a tool for assessing results and consequences taxation.

The development of strategic management at the organization level has led to the emergence of tax planning as an element of the organization's financial management in order to reduce the negative impact of taxation on the results of operations, the implementation of which requires the development of tax analysis procedures. Recognition of the active role of the external environment in the activities of the organization made it possible to rethink the meaning of tax analysis, without limiting its task of "optimization" of tax expenditures. For the harmonious interaction of the organization with the surrounding socio-economic environment, tax analysis ensures the alignment of interests in the taxation process, reflecting the relationship between structural levels public finance and the finance of business entities as agents of economic relations. The development of a conceptual theoretical basis for the interpretation of performance, taking into account the impact of taxation, opens up opportunities for solving a number of practical problems, including one of the main ones being the coordination of the interests of the state and business, which directly determine the sustainable socio-economic development of Azerbaijan.

Дослідники в області податкового аналізу ввели і використовували в своїх, дслідженнях певні терміни і поняття. Більшість концепцій з метою цього дослідження охоплюють таке: податковий тягар, операційні податкові витрати, податкове середовище, податкові пільги. В офіційнихдокументах в тій чи іншій формі також використовується спеціальна термінологія, що стосуєтьСя податкового аналізу, проведеного державними органами. Аля проведення такого дослідження в статті проаналізовані та узагальнені ці терміни.

Слід зазначити, що в результаті синтезу ряду спеціальних та галузевих областей наукового знання економічний аналіз У ХХ СТ. СТав Самостійною галуззю науки. Під вПливом потреб практики народжуються нові перспективні наукові напрями економічного аналізу, одним 3 яких є податковий аналіз. Виникнення податкового аналізу пов 'язано з необхідністю оцінки та врахування вПливу на результати господарської діяльності податкової системи, що впливає на фінансові інтереси різних груп економічних агентів. Накопичений практичний,досвід, дозволяє зробити перші кроки увизначенні предмета, методу і цілей податкового аналізу, які є фундаментальними концепціями, які підтверджують появу самостійного наукового напряму в економічному аналізі.

Економічний зміст податків виражається відносинами в формуванні державних фінансів. У процесі оподаткування, здійснюваного в рамках ієрархічної структури фінансової системи країни, податкові платежі відображають потоки фінансових ресурсів і взаємозв'язок між структурними рівнями - державними фінансами і фінансами господарюючих суб'єктів, як агентів економічних відносин. ОАна із кАючових проблем оподаткування - це неминучий конфлікт, що виникає в процесі реалізації функцій дер- 

що надходять до бюджетної Системи, є, доодом державного сектора і одночасно одним із видів витрат ААя ПАатника податків. Зазначені питання, на наш погАяд, вимагають Всебічного вивчення.

Key words: tax analysis, tax burden, operational tax costs, tax environment, tax discounts.

Ключові слова: податковий аналіз, податковий тягар, операчійні податкові витрати, податкове середовище, податкові знижки.

\section{DEFINITION OF THE PROBLEM}

The practical need for scientific approach to the study of the diversity of issues of economic analysis in different areas led to the isolation and development of its individual scientific directions. A knowledge system that studies the impact of taxation on conditions for the sustainable development of economic entities, forms a separate scientific direction - tax analysis. Meanwhile in economic analysis until recently, the study of these issues was not given due attention. At the same time, certain issues of tax analysis developed within the framework of other sciences, and the term "tax analysis" is mainly associated with macroeconomic level.

Modern business conditions of organizations in a market economy for making effective economic decisions dictate the need analysis of the whole variety of internal and external factors affecting financial and economic activities, including factors of tax expenses.

\section{ANALYSIS OF LATEST RESEARCH AND PUBLICATIONS}

In the scientific works of Chipurenko E.V. "Methodology of tax analysis and assessment of the impact of the tax system on the activities of commercial organizations", Kalbiyev Y.A. "Fiscal policy and problems for regulation of the national economy", Nikiforova N.A., Milovidova S.N. "Tax Analysis" tax analysis issues are extensively analyzed.

\section{PURPOSE OF ARTICLE}

The main purpose of research is to investigate the main conceptions used in "tax analysis", to substantiate the difference between subjects of tax relations, also to elucidate the issued roused more interest for entrepreneurs and to create a condition for creating of maximal sufficient condition for them.

\section{PRESENTATION OF PRINCIPAL PART}

\section{Introduction}

One of the important used in tax analysis is the conception of tax burden. According to E.V. Chipurenko, tax burden of the organization is a group of the main universal characteristics of the condition of organization giving an opportunity to single description of business activity and its results necessary to conduct supervision over selection of management decisions and the impact of taxation to fulfillment of organizational functions by considering the impact of tax environment [1, p. 50].

T.V. Kulikova determines tax burden at micro level as indicator giving an opportunity to measure the number of results of mutual impacts with quantity among subjects of tax relations. The absolute tax burden is general amount of tax costs of economic entities collected for payment on certain period. The relative tax burden is amount of tax costs of economic entities connected with comparative base during a certain period [2]. The authors appeal to different taxes used in the literature, for example "tax burden", "the whole tax collection" and other such synonyms in many works analyzed on the existing research subject, in the term of "tax burden". According to us, the term of "tax burden" has been formed well, because it is used in the documents published in official sites of the Ministry of Taxes of the Republic of Azerbaijan and it comes across in special literature more. The term of "tax burden" is used in the source with English language.
The discounted taxation, simplification of taxation, its stability is one of the issues roused interest for entrepreneurs among priority directions of state collection. Recently, several changes made in the Tax Code of the republic will give opportunity for creating of maximal efficient condition for development of small business in the republic by the way of simplification of accounting system, simplification of tax burden of small entrepreneurial subjects in the country. The specialists think that, increase of tax burden for small entrepreneurial subjects is contrary to the logic of tax reforms and priorities of state policy in the field of stimulating of small business. As mentioned by prof. S.V. Salahov, "...tax burden determined at macroeconomic level describes the real appearance in the form of distorted. So, tax burden calculated as comparison of CIP of taxes paid by tax payers in the country doesn't take into account the different characteristics of payers, for example, the structure of production and turnover costs in regard to obtaining of their incomes, differentness of scientific and fund capacity of production, the level of profitability and other important factors" [3, p. 361].

In accordance with method called "reaganite economics" and used in USA at the beginning of 80 s of the last century, the state mitigates tax burden by fixing minimal tax rates for entrepreneurs and decreases its costs and the costs directed to social program. The main purpose of this policy is to provide the priority development of capital and to stimulate the investment activity. It shall be noted that, economic development policy is applied in the cases when the danger of crossing of stagnation to economic crisis arises in the country economy.

The economists think that, tax burden covers the responsibility of all tax payers before law. Because, putting of additional taxes is not acceptable for entrepreneurial activity depending on property and organizational-legal forms. So, taxes are accepted by competent authorities. So, putting of tax and duties on payers is protected by the state [4, p. 235; 5, p. 356].

Principal part according to the theory of American economists prof. A.Laffer, increase of tax rates till certain limit gives an opportunity for increase of tax entries, receives its maximum price till that limit. After a while, budget entries decrease sharply. Laffer thinks that, increase of tax burden in the non-substantiated form causes to development of secret economy. According to Laffer, only decrease of tax burden stimulates the entrepreneurial activity and develops the initiative. It is clear that, the growth of state incomes doesn't occur on the account of growth of tax burden of product (work and service) manufacturers, it occurs on the basis of expanding of taxation base on the account of increase of production. But, according to specialists, "Laffer curve" doesn't create an exact notion about omitted quantity of taxes received for state budget by reflecting only the dependence indicated [6, p. 134]. The level of that quantity depends on financial condition of tax payers acting in concrete country and economic situation existing in that country.

Certain indicators system in regard to establishment of tax system has been developed in the countries with developed market economy. It is impossible to speak about entrepreneurial activity in the cases excessing the last possible price of those indicators. The practice shows that, if $30-40 \%$ of incomes are received from tax payers, the decrease of collection and the solution of capital to the 
country economy decreases. The economists think that, of taxation level gives an opportunity to receive $40-50 \%$ of the incomes from tax payers, this case will decrease the interest of entrepreneur in initiative and expanding of production [6, p. 134].

In general, the indicator of tax burden determined on common tax system has several serious shortages. The main serious shortage consists of it that, this indicator doesn't take into account the individual characteristics of concrete tax payer. But, taxes are determined by the state, therefore the calculation of this indicator has important significance.

As it is known, there are many enterprises differing one other for types of activity and many features in every country, this variety exerts its influence to formation of their taxation base and amount of taxes paid by them. Certainly, the consideration of all of these while formation of tax system bears the complicated character. But, we think that, there is a need for development of new indicator to be calculated by considering these parameters.

The methods of calculation of special weight of taxes in CIP determining the level and dynamics of tax burden in macro level, determined on the basis of the main macroeconomic indicators of country economy and level of tax burden per population, tax potential among different approaches to calculation of tax burden exist in the world practice. But we think that, such approaches to calculation of tax burden exclude the comparison of economic results of different economic entities representing different fields of the economy. Hereby, it shall be acknowledged that, use of these methods at the time of calculation of tax burden at macro level is advisable.

The comparison of all tax amounts received from tax payers with percentage in the capacity of CIP shall be found not depending on payment of tax to which level budget and extra-budgetary funds to calculate tax burden indicator at macro level in tax practice of the world countries.

The research conducted shows that, real tax burden of enterprises in our republic is considerable upper than average indicator on the country. Therefore, we think that, the characteristics of country economy shall be taken into consideration at the time of impact of taxes to entrepreneurial activity. The point is that, all of tax payers were treated equally not depending on property form and administrative-territorial placement while forming tax system in the republic. Analysis shows that, the main tax burden bears on certain, gradually limited tax payers. Therefore, as confirmed by specialists, "...the problem of decreasing of tax burden in republican tax system is closely regarded to expanding of taxation base, elimination of problem in payments in the economy and strengthening of financial-tax discipline as a result of attraction of all financial-economic transactions performed by economic agents to taxes" [6, p. 142-143].

The research shows that, tax burden indicator calculated in comparison with CIP doesn't reflect exactly the tension of tax liabilities on enterprises of separate sectors of economy and different production fields. So, use of comparative indicator reflecting tax burden of economic agents is advisable. The current financial condition of economic subjects engaging in entrepreneurial activity in our republic and the present tendency of their development gives grounds to say that, $30-40 \%$ of comparative tax burden indicator calculated on the basis of value established newly in the country is more advisable. It shall be emphasized that, higher tax burden in leading fields of the economy weakens the entrepreneurial activity, also bankrupts their financialeconomic work. Therefore, non-excess of maximal comparative tax burden level per any economic subject than $50 \%$ is recommended.

According to prof. Y. Kalbiyev, though discounted regime of taxation justified itself, "...the motive of its application for the great majority of small entrepreneurship is very negative - it shall be evaded the taxation legally" $[5$, p. 106]. The economist-scientist thinks that, the negative role of this tax as official method of evasion from VAT at the time of entering of special accounts may increase much more. So, there is a need for establishment of efficient tax environment within traditional VAT for small entrepreneurship.

The important duty of tax analysis is evaluation of tax condition in referring to tax terms of economic subject under influence of external and internal factors. The influence of external factors is determined with impact of different normative and legal acts to the activity determining the running terms of economic subject. Internal factors - are the whole of characteristics such as property form of organization, organizational-legal form, types, character, scope of activity, accepted accounting policy, etc.

Some scientists use the concept of tax environment in their researches, which is a set of various factors related to the taxation system that directly and indirectly affect the activities of economic entities.

E.V. Chipurenko uses the term "indicators of tax environment" to determine the indicators obtained as a result of the analysis of the tax environment. At the same time, indicators are distinguished by the scientist at three levels: at country level, at the field level, at the organization level. Indicators of the tax environment at the organizational level are an indicator of the tax burden, as well as the suitability of the tax environment for the taxpayer $[1$, p. 76; 8, p. 60].

Tax liabilities are tax costs of the organization. In the economic literature, it is accepted to distinguish between concepts such as costs and expenses. Similarly, some authors distinguish differences between tax expenses and costs.

These concepts are specified in the presentation of E.G.Dedkova named "the analysis and forecasting of tax costs in industrial enterprises", at the same time tax costs are meant the liabilities calculated related to the tax, and tax expenses are meant tax liabilities paid actually by the author [7, p. 13].

In the economic literature, costs mean the value written off to the production of materials, raw materials and others, then costs reduce the financial result. The organization's expenses are recognized as writing off of assets and (or) reduction of economic benefits as a result of creation of liabilities caused to the reduction of capital [9, p. 147]. The terms "expenses" and "costs" are used as synonyms in the Tax Code of the Republic of Azerbaijan.

In our opinion, all taxes calculated for any reason, regardless of their actual payments, are expenses remaining in the place, except for taxes, which are included in indirect costs and then distributed among the types of products, works and services by increasing the prime cost. The amount of these taxes, in whole or in part, forms tax expenses as a result of the sale or other failure of these products, works or services until their prime cost are written off. Transit (operating) costs are understood as interaction costs between economic entities. Such costs are any necessary resource costs that are not directly attributable to the production of economic goods, but ensure the successful implementation of this process [10].

As the term "costs" isn't used in the normative legal acts on accounting and tax accounting, then we will use the term "operating tax expenses".

The organization's tax expenses ion operations are costs related to the application of the taxpayer's duties determined by the organization under the Tax Code, i.e tax accounting, issuance of tax declaration and other documents necessary for tax control, elimination of detected violations of tax legislation and other fulfillment.

Important concepts for tax analysis purposes are the concept of tax regime, which understood as a certain rule for the calculation and payment of taxes established by tax legislation, as well as the concept of "compatibility of tax regimes", which allows the simultaneous application of several tax regimes depending on the type of economic activity performed by the organization. In the economic literature, the terms "tax regime" and "tax system" are used as synonym. 
Alternative taxation regimes - general taxation system (only alternative under certain conditions), simplified tax system, tax system for agricultural producers, as well as nonalternative, i.e absolute tax regime were defined in the Tax Code. The alternativeness means the possibility of the selection of tax system if the necessary conditions determined by the economic entity in the Tax Code are met.

Optimization of taxation is an activity aimed at using the best possible options of methods and techniques of the regimes provided for in the tax legislation for the calculation of taxes, as well as discounts, allocations in order to reduce tax expenses and keep tax risks at an acceptable level.

In his study, Hoftman A.P. uses the term "tax corridor" which is presented by the scientist as "the establishment of a function of targeted optimization of taxation of the enterprise with minimal tax risk". It presents the conception of lower and upper boundaries of the tax corridor [9, p. 147].

According to the scientist's words, the lower limit of the tax corridor is the minimum quantity of the tax burden, in case the tax risk is not the maximum. The upper limit of the tax corridor is the maximum quantity of the tax burden if the efficiency of the financial and economic activities of the economic organization is maintained.

The term "tax field" is often used in tax planning and forecasting. The organization's tax field is the set of taxes and their features provide by its tax regime.

Also, the term, which is often used in researches related to the taxation, is the expression of "tax discount". The tax discount mainly means the reduction of tax base, the receipt of tax discount, granting of tax benefits, the application of a lower tax rate and reduction of tax liability as a result of refund from the budget (recovery) and refund of tax compensation. It is necessary to distinguish the justified and unjustified tax discounts. The existence of unjustified tax discounts shows the illegal actions of the taxpayer.

\section{CONCLUSION}

1. The conduction of radical reforms in the tax system should, first of all, intend the application of tax discounts for entrepreneurship and the improvement of existing rates. At the same time, the state can concretize all the existing forms of tax discounts of the world countries in relation to this or other economic entities and this or other areas, which is intended to stimulate economic activity as follows: finding opportunities to further reduce the rates of some taxes (especially profit tax and VAT); - application of various tax discounts, as well as exemption from taxes in the first stages of activity of enterprises operating in the real sector fields, which are intended to stimulate economic activity; - to keep at the disposal of local executive authorities a part of taxes collected from business entities in order to accelerate the development of economic regions of the republic; - application of the discounted tax to investments directed by entrepreneurs to underdeveloped, as well as strategically important regions of the republic; - conducting tax audits on a selective basis and when there is a good reason for it etc.

2. Several tax discounts are carried out for many economic entities that support small business, including small business support funds, investment and leasing companies, credit and insurance companies, advertising and information companies and others by the government in the developed market economy countries. We consider that this practice of the world countries in the field of tax policy shall be kept in mind.

However, it should be noted that when using any form of international practice, it would be wrong to apply them blindly, to repeat them as they are, and it would not give the expected results. Therefore, we consider that the experience of the world countries in the field of tax discounts must be organically connected with the nature of the tasks and the direction of implementation of the requirements of the current stage of our economic development. These discounts include the application of low and different taxes for areas that are engaged in production in the early stages of its activity, necessary for the development of the economy, economic regions and types of activities, and exemption from tax for a certain period etc.

3. It is important to note that the same concepts used in normative legal acts in the field of accounting and tax accounting often differ. So, when income and expenses are classified, terms such as "incomes (income) on the ordinary activity types", "other incomes", " expenses (sales expenses) on the ordinary activity types", "other expenses" in modern accounting, and "incomes from sales", "non-sale incomes", "expenses related to the production and sales", "non-sale expenses" in tax accounting are used. Contrary to the tax accounting, the modern accounting isn't used the term of reserves, but instead used the expressions of "estimated liabilities" and "estimated reserves". Due to the differences between the terminological apparatus of accounting and tax accounting, it is necessary to determine which terms will be used in tax analysis.

4. The database of tax analysis is mainly the information of the tax accounting system that is independent of the accounting system in the organization or will be established on its basis. In the second case, the information source for tax analysis is actually the accounting system. Moreover, one of its information sources will be accounting (financial) reports to solve individual problems of tax analysis, for example, to assess tax risks according to generally available criteria, regardless of how the organization forms the tax accounting system.

The ability to use both the tax accounting system and the accounting system as a database for tax analysis, in our opinion, allows the use of the terms of both systems in tax analysis.

\section{References:}

1. Chipurenko, E.V. (2012), Methodology of tax analysis and assessment of the impact of the tax system on the activities of commercial organizations: Dissertation of Doctor of Economics: 08.00.12, 08.00.10/ Chipurenko Elena Viktorovna, Moscow, Russian Federation.

2. Kulikova, T.V. (2004), Tools for planning the tax burden of economic entities: Dissertation of the Candidate of Economic Sciences: 08.00.10/Kulikova Tatyana Veniaminovna - Ivanovo, Russian Federation.

3. Salahov, S.V. (2004), Problems for state regulation of the agrarian sector, "NURLAR", Baku, Republic of Azerbaijan.

4. Alirzayev, A.G. (2005), Problems of socio-economic development of Azerbaijan in the context of reforms and acceleration strategy: experience, trends and perspective directions. "Adiloghlu" publishing house, Baku, Republic of Azerbaijan.

5. Kalbiyev, Y.A. (2005), Fiscal policy and problems for regulation of the national economy, "Tafakkur"NPM, Baku, Republic of Azerbaijan.

6. Nikiforova N.A., Milovidova, S.N. (2020), Tax Analysis, Knorus. Moscow, Russian Federation.

7. Dedkova, E.G. (2010), Analysis and forecasting of tax costs in industrial enterprises: dissertation of the candidate of economic sciences: 08.00.10/ Dedkova Elena Gennadevna -Oryol, Russian Federation.

8. Transaction costs [Electronic resource] // Portal financial sciences. - Available at: http://www.mirkin.ru/ docs/dumnaya/net03.pdf (Accessed: 01.09.2014).

9. Hoftman, A.P. (2008), Methodology for assessing the tax burden of small businesses within the "tax corridor": Dissertation of the Candidate of Economic Sciences: 08.00.10 / Hoftman Anna Pavlovna - Yaroslavl, Russian Federation.

10. Tax benefit: concept, signs, practice // Internet edition of Clerk.ru. - Available at: http://www.klerk.ru/ law/articles/129482 (Accessed: 01.02.2014).

11. Musayev, A. F. (2004), Economic problems of the tax policy, "Elm", Baku, Republic of Azerbaijan.

Стаття надійшла до редакиіï 22.09.2020 p. 